Biol. Stud. 2014: 8(3-4); 53-60 • DOI: https://doi.org/10.30970/sbi.0803.382

www.http://publications.Inu.edu.ua/journals/index.php/biology

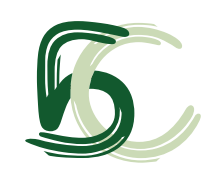

UDC 577.353.24+577.353.3+57.04

\title{
FEATURES OF ACTOMYOSIN SUPERPRECIPITATION REACTION IN DIFFERENT ENVIRONMENT CONDITIONS
}

\author{
O. V. Tsymbalyuk, K. I. Bogutska, A. Yu. Nyporko, T. L. Davidovska \\ Taras Shevchenko National University of Kyiv, 64, Volodymyrska St., Kyiv 01601, Ukraine \\ e-mail: otsymbal@bigmir.net
}

The influence of divalent cations $\left(\mathrm{Cd}^{2+}, \mathrm{Zn}^{2+}, \mathrm{Sr}^{2+}\right)$ and staphylococcus protein $\mathrm{A}$ on the superprecipitation reaction of cardiac muscle actomyosin was investigated using methods of preparative protein chemistry, optical spectroscopy and mechanokinetic analysis. It was shown that the metal ions in the range of concentrations $0.1-5 \mathrm{mM}$ inhibit the $\mathrm{Mg}^{2+}$-dependent SPP reaction of actomyosin cardiac muscle and alter the kinetic parameters of this process. It was revealed that protein A modulates superprecipitation dynamics decreasing the maximal value of optical density and time of its halfmaximum achievement as well as starting and normalized superprecipitation rates. Thus, investigated factors are able to influence the actin myosin interaction changing their functional parameters of proteins from cardiomyocyte contractile complex. The kinetic characteristics of actomyosin superprecipitation are sensitive to the influence of physicochemical and pharmacological factors and can be used to study their influence on the molecular mechanisms of muscle contraction.

Keywords: actomyosin, superprecipitation, kinetic parameters, metal ions, S. aureus protein $\mathrm{A}$, cardiac muscle.

\section{INTRODUCTION}

Muscle contraction-relaxation is a dynamic oscillatory process that consists of interrelated and interdependent physical and chemical reactions. Superprecipitation (SPP) reaction can be consider as a certain model system to investigate the structural organization and functional properties of muscles actomyosin complex because the process of muscle contraction is associated namely with the formation of actomyosin complex and its subsequent conformational changes due to the energy released as a result of ATP hydrolysis by myosin $[9,14]$. In other words, SPP approximately corresponds to the structural rearrangements of main contractile proteins during the muscle contraction. In general, the muscle contraction study can either accent on the properties of individual protein components of muscle to reconstruct from them mechanochemical model systems simulating the contractile process or reproduce the structural and functional state actomyosin complex during the reaction SPP. SPP is the process of myosin aggregates' compaction with actin filaments due to ATP hydrolysis, which occurs in the presence of such aggregates in suspensions, sediments and actomyosin gels [16].

ISSN 1996-4536 (print) • ISSN 2311-0783 (on-line) • Біологічні Студії / Studia Biologica • 2014 • Том 8/№3-4 • С. 53-60 
Thus, this model system may be used to investigate several properties of the muscle contractile apparatus (actin-myosin interaction and its regulation, regularities of selfassembly of contractile systems, etc.) as well as the influence of different physical, chemical and pharmacological factors.

One of the general problems of biology that attracts time-stable attention of researchers is full comprehension of the regularities of cell functions in organism under the influence of various physical and chemical factors. Thus, it's well known they can stimulate the pathological changes in the body, but the molecular and membrane mechanisms of their implementation aren't completely understood to date.

It's known that Staphylococcus aureus is one of the most lethal human pathogens. High pathogenicity of Staphylococcus is explained particularly by its ability to produce a number of antigens. The active substances protein A, teichoic acid, peptidoglycan and toxins $[7,8,11]$ are the most studied among them. Staphylococcus aureus protein A is surface antigen of bacterium. It's covalently bound to peptidoglycan component of the cell wall. Protein A considers to be the major factor of the staphylococcus pathogenicity [8]. At present time, the mechanisms of golden staphylococcus penetration into the organism and main stages of the complex immune response to its invasion are well investigated; however, the influence of bacterial substances on individual tissues is still unclear.

Thus, our aim consisted in the investigation of myocardium actomyosin SPP reaction changes induced some divalent metal ions and immunologically active substances of Staphylococcus aureus.

\section{MATERIALS AND METHODS}

Actomyosin (from bovine heart) extraction was carried out for an hour by the solution containing $0.2 \mathrm{M} \mathrm{KCl}, 0.15 \mathrm{M}$ Tris- $\mathrm{HCl}, 1 \mathrm{mM}$ EDTA, $5 \mathrm{mM} \mathrm{MgCl}, 0.2 \mathrm{mM}$ phenylmethylsulfonylfluoride (PMSF), $1 \mathrm{mM} \mathrm{NaN}_{3}, 3.5 \mathrm{mM}$ ATP, pH 7.5. Actomyosin was precipitated by adding 10 volumes of cold distilled water to the solution previously diluted by $0,1 \mathrm{~N}$ vinegar acid to $\mathrm{pH}$ 6.2. The protein fraction was separated by centrifuging at $3000 \mathrm{~g}$ for $15 \mathrm{~min}$. After protein dissolving in $40 \mathrm{mM} \mathrm{Na}_{4} \mathrm{P}_{2} \mathrm{O}_{7}, \mathrm{pH} 7.5,1 \mathrm{mM}$ DTT, $1 \mathrm{mM}$ $\mathrm{NaN}_{3}$, which was followed by dialysis, it was centrifuged for an hour at 100,000 $\mathrm{g}$ [3].

Measurement of superprecipitation. Kinetic curves of actomyosin superprecipitation were recorded on SPECORD M40 spectrophotometer (Germany). The value of native protein superprecipitation was taken as over $100 \%$. From the obtained kinetic curves, the value of superprecipitation was calculated as $\left(D_{\max (450)}-D_{0}\right)$, where $D_{0}$ and $D_{\max (450)}$ are the initial and the maximum optical densities of actomyosin during the SPP reaction, respectively. Superprecipitation induced by adding ATP $(0.1 \mathrm{mM})$ in $0.1 \mathrm{mg} / \mathrm{ml}$ natural actomyosin, $0.1 \mathrm{mM} \mathrm{CaCl}_{2}, 1 \mathrm{mM} \mathrm{MgCl}_{2}, 150 \mathrm{mM} \mathrm{KCl}, 0.1 \mathrm{mM}$ EGTA and $20 \mathrm{mM}$ Tris- $\mathrm{HCl}$ at $\mathrm{pH} 7.5$ and $25^{\circ} \mathrm{C}$, was examined using method [15], and the change in the absorbance at $450 \mathrm{~nm}$ was checked.

In the studied samples, protein complex SPP changes were measured in the presence of metal ions and immunologically active substances (the protein A) of Staphylococcus aureus at $10^{-6}$ to $10^{-2} \mathrm{mg} / \mathrm{ml}$ concentration range. Protein A for the study was kindly given by Prof. L.S. Kholodna.

Method of kinetic analysis of SPP curves. From the analyses of kinetic curves the effect of the value of superprecipitation $\left(D_{\max (450)}-D_{0}\right)$, time $t_{1 / 2}$, required for achievement of half of its value was determined, and the normalized maximal rate of this reaction $v_{n}$ was also calculated.

ISSN 1996-4536 (print) • ISSN 2311-0783 (on-line) • Біологічні Студії / Studia Biologica • 2014 • Том 8/№3-4 • С. 53-60 
The normalized maximum rate of actomyosin units forming $\left(v_{n}\right)$ calculated using a modification of the method of kinetic analysis $[5,18]$ was used during analysis of the experimental curves. To obtain $v_{n}$ the graphics of optical density change in the coordinates $\left\{\ln \left[\left(D_{\max }-D\right) / D\right] ; \ln t\right\}$ were firstly linearized. The next kinetic characteristics were determined from the linearized graphics: In $\tau$-segment that cuts on the $x$-axis line drawn through the experimental points, and the empirical parameter $n-$ tangent of this line slope, which characterizes the steepness of $D(t)$ dependence. These kinetic parameters were used to calculate the normalized SPP rate, which was normalized to the maximum (stationary) values of optical density:

$$
V_{n}=\frac{(n-1)^{\frac{n-1}{n}} \cdot(n+1)^{\frac{n+1}{n}}}{4 n \tau}
$$

Statistics. Experimental data were processed with statistical methods using soft Microsoft Office Excel. Statistical significance of differences between two means was assessed by Student's $t$ test for paired data. For significance linear function approximation was performed Fisher's F-test; coefficient of determination $\left(R^{\wedge} 2\right)$ were not lower than 0.9. All values are expressed as mean \pm SE mean for $n$ number of experiments. $P$ values $<0.05$ were considered as significant.

\section{RESULTS AND DISCUSSION}

The superprecipitation of actomyosin is generally accepted to be simulate the phenomenon of muscle contraction in vitro. If we consider the process of precipitate formation and dissociation during the actomyosin SPP, it mainly reproduces the process of muscle contraction - in the presence of magnesium ions and ATP the calcium ions cause muscle contraction, and the removal of calcium EGTA ions in the presence of ATP causes a muscle relaxation [12]. A comparison of the kinetic curves for $\mathrm{Mg}^{2+}$-dependent SPP reaction of myocardium actomyosin in the presence of various divalent ions $(0.1 \mathrm{mM})$ is shown on Fig. 1.

Fig. 1. Kinetic curves of $\mathrm{Mg}^{2+}$-dependent SPP reaction of myocardium actomyosin in the presence of various divalent ions $(0.1 \mathrm{mM}): 1$ - without $\mathrm{Me}^{2+}$ (control); $2-\mathrm{Sr}^{2+} ; 3-\mathrm{Zn}^{2+} ; 4-\mathrm{Cd}^{2+}$

Рис. 1. Кінетичні криві $\mathrm{Mg}^{2+}$-залежної реакції суперпреципітації актоміозину серцевого м'яза за наявності різних двовалентних іонів (0,1 мМ): 1 - без $\mathrm{Me}^{2+}$ (контроль); 2 - $\mathrm{Sr}^{2+} ; 3-\mathrm{Zn}^{2+}$; $4-\mathrm{Cd}^{2+}$

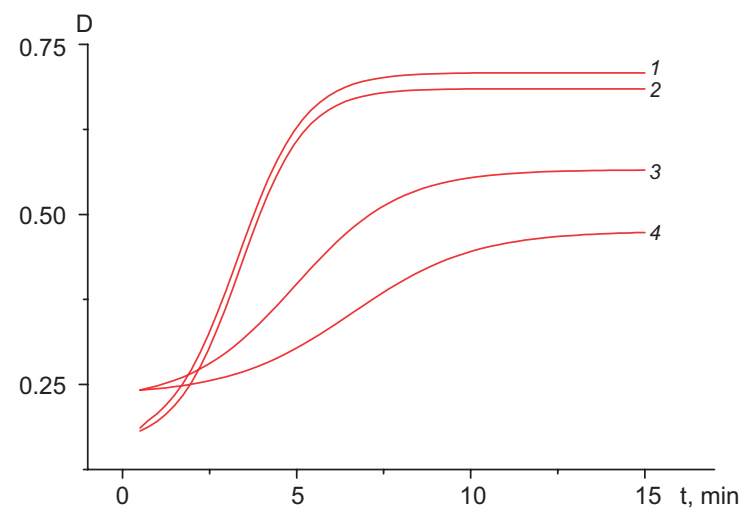

Actomyosin SPP reaction curves are characterized $t_{1 / 2}$ values that are more than the control for SPP in the presence of $\mathrm{Zn}^{2+}$ (as shown in our previous work [3]) and $\mathrm{Cd}^{2+}$. In the presence of $\mathrm{Sr}^{2+}$ the actomyosin SPP has parameters $t_{1 / 2}$ and $v_{0}$ similar to these ones in the presence of $\mathrm{Ca}^{2+}$, i.e. index time of half-maximal density is almost the same in the test and in the control. By increasing the time required to reach half $D_{\max }-D_{0}$, ions can be arranged in series: $\mathrm{Sr}<\mathrm{Zn}<\mathrm{Cd}$. SPP actomyosin reaction in the presence of various metal ions was also characterized by parameters $v_{n}($ Tabl. 1). 
Table 1. The values of actomyosin SPP kinetic parameters in the presence of the studied metal ions ( $\mathrm{Me}^{2+}$ concentration is $0.1 \mathrm{mM}$ )

Таблиця 1. Значення кінетичних параметрів реакції суперпреципітації актоміозину за наявності різних іонів металів (Ме ${ }^{2+}$ в концентрації 0,1 мМ)

\begin{tabular}{c|c|c|c|c|c}
\multirow{2}{*}{ Cation } & \multirow{2}{*}{$\begin{array}{c}\text { Curve } \\
\text { number }\end{array}$} & \multicolumn{5}{|c}{ SPP actomyosin parameters } \\
\cline { 3 - 6 } & 1 & $D_{\max }$ & $t_{1 / 2}, \min$ & $v_{0}, \%$ & $v_{\mathrm{n}}, \%$ \\
\hline Control & 0.74 & 2.4 & 125 & 97 \\
\hline $\mathrm{Sr}^{2+}$ & 2 & 0.73 & 2.5 & 116 & 94 \\
\hline $\mathrm{Zn}^{2+}$ & 3 & 0.51 & 3.5 & 95 & 93 \\
\hline $\mathrm{Cd}^{2+}$ & 4 & 0.48 & 4.2 & 67 & 48 \\
\hline
\end{tabular}

To completely consider the dynamics of the formation of the complex of actin and myosin, it's important to use parameters that would quantitatively characterize not only the initial stage of SPP reaction $\left(v_{0}\right)$, but can be applied to compare the kinetics of actomyosin aggregates' formation regardless of the fixed maximum $\left(D_{\max }\right)$. The normalized maximum SPP rate $\left(v_{n}\right)$ was used as a reference parameter. Kinetic analysis of SPP curves shows that strontium ions don't change the normalized maximum rate $\left(v_{n}\right)$ in the entire range of investigated concentrations (0.1-5 mM) (see Fig. 2, A). Addition of $\mathrm{Zn}^{2+}$ and $\mathrm{Cd}^{2+}$ ions in the incubation medium is accompanied by a dose-dependent decrease of $v_{n}$ rate (Fig. $2, B$ ). Thus, inhibition of this parameter is reliably caused by $\mathrm{Zn}^{2+}$ concentration of $0.5 \mathrm{mM}$ and higher [3].
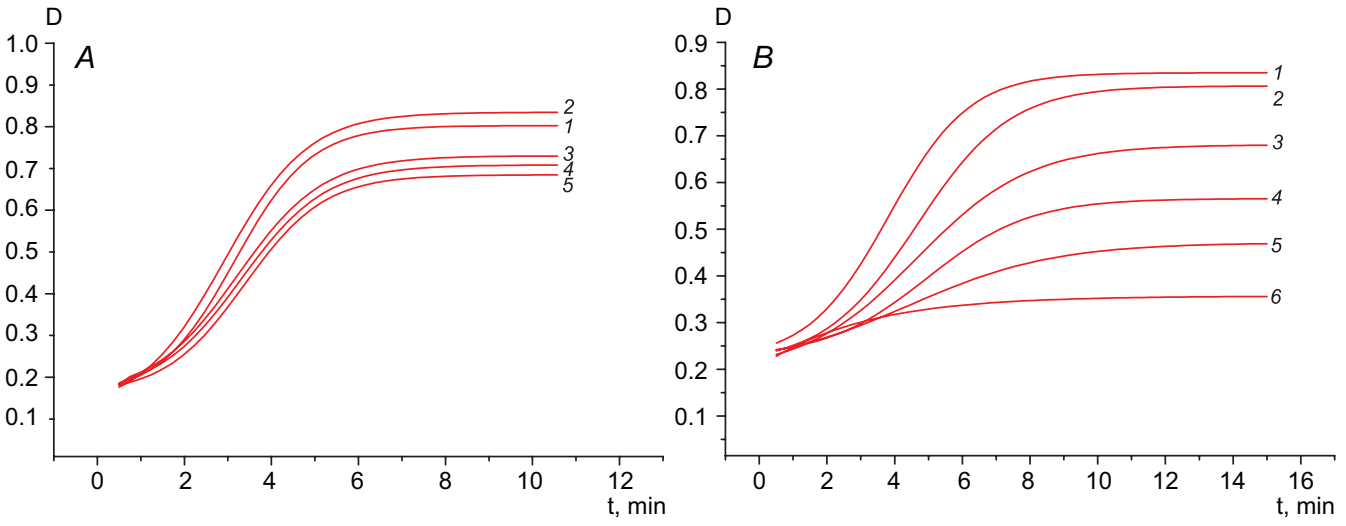

Fig. 2. Kinetic curves of myocardium actomyosin SPP reaction: $\boldsymbol{A}$ - at various $\mathrm{SrCl}_{2}$ concentrations (mM): 1 - without $\mathrm{Sr}^{2+}$ (control); $2-0.1 ; 3-0.5 ; 4-1 ; 5-5 ; \boldsymbol{B}$ - at various $\mathrm{CdCl}_{2}$ concentrations $(\mathrm{mM}): 1-$ without $\mathrm{Cd}^{2+}$ (control); $2-0.01 ; 3-0.05 ; 4-0.1 ; 5-0.5 ; 6-1$

Рис. 2. Кінетичні криві реакції суперпреципітації актоміозину серцевого м'яза: $\boldsymbol{A}$ - у разі додавання різних концентрацій $\mathrm{SrCl}_{2}(\mathrm{MM}): 1$ - без $\mathrm{Sr}^{2+}$ (контроль); $2-0,1 ; 3-0,5 ; 4-1 ; 5-5 ; \boldsymbol{B}$ - у разі додавання різних концентрацій $\mathrm{CdCl}_{2}(\mathrm{MM}): 1$ - без $\mathrm{Cd}^{2+}$ (контроль); $2-0,01 ; 3-0,05 ; 4-0,1$; $5-0,5 ; 6-1$

The most significant changes of SPP kinetics are caused by $\mathrm{Cd}^{2+}$ ions: $v_{n}$ value reduces by $33 \%$ already in the presence of $0.05 \mathrm{mM} \mathrm{Cd}^{2+}$ and by $71 \%$ at $1 \mathrm{mM} \mathrm{Cd}^{2+}$ (see Fig. 2, B). Thus, obtained data testifies that all studied divalent cations $\left(\mathrm{Sr}^{2+}, \mathrm{Zn}^{2+}\right.$, $\mathrm{Cd}^{2+}$ ) can provide the actomyosin SPP reaction, but to various degrees compared to control. The investigations have shown that the effect of cations on actomyosin SPP correlates with changes of myosin ATPase activity under similar conditions [17].

ISSN 1996-4536 (print) • ISSN 2311-0783 (on-line) • Біологічні Студії / Studia Biologica • 2014 • Том 8/№3-4 • С. 53-60 
The effect of pristine water-soluble fullerene $C_{60}$ and carbon nanotubes on superprecipitation reaction of rabbit skeletal muscle natural actomyosin was been similar to our results, namely an increase of actomyosin superprecipitation by fullerene and nanotubes [1, 2].

For the next investigation we use protein $\mathrm{A}(\mathrm{pA})$ of Staphylococcus aureus in purified $(\mathrm{PpA})$ and bacterial cell-bound (CBpA) forms. The implementation of the SPP reaction in the $\mathrm{pA}$ presence revealed that this substance in all studied concentrations $\left(10^{-6}-10^{-2} \mathrm{mg} / \mathrm{ml}\right)$ reduces the maximum value of optical density after ending of SPP reaction $\left(D_{\max }\right)$ in various degrees (Fig. 3, $A$ and $B$ ), as well as achieving of optical density half-maximum $\left(t_{1 / 2}\right)$, and increases the initial rate of SPP reaction $\left(v_{0}\right)$.
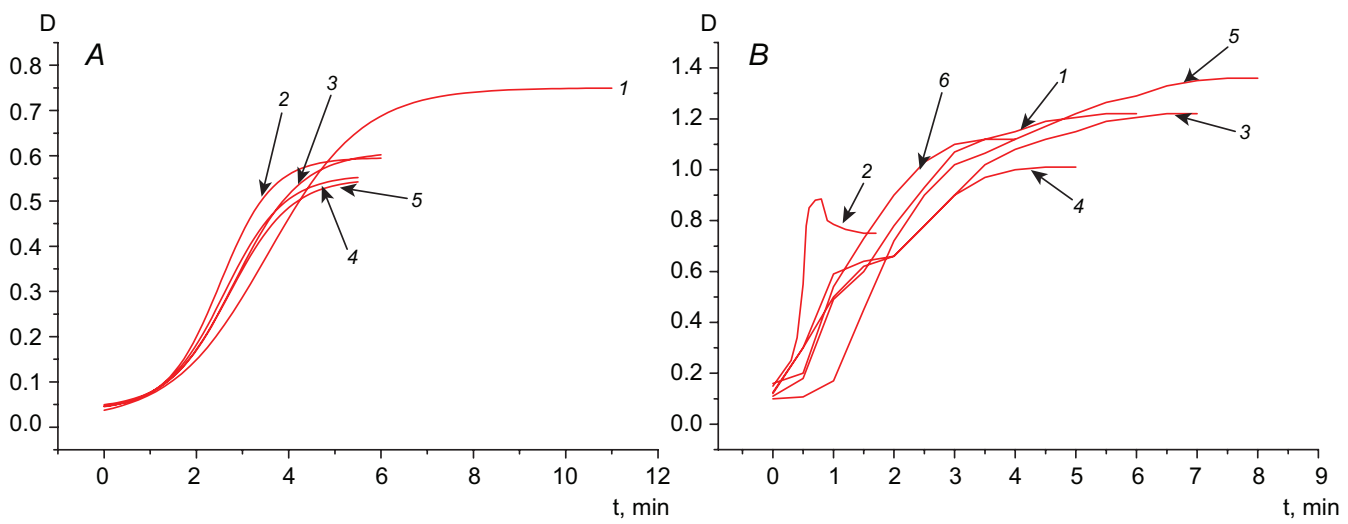

Fig. 3. Curves of myocardium actomyosin SPP in control (1) and in the presence of cell-bound protein $A$ from Staphylococcus aureus at concentrations of $10^{-2}(2) ; 10^{-3}(3) ; 10^{-4}(4)$ та $10^{-5}(5) \mathrm{mg} / \mathrm{ml}(A)$ and in the presence of purified protein A from Staphylococcus aureus concentrations $10^{-2}(2) ; 10^{-3}(3) ; 10^{-4}(4)$; $10^{-5}(5)$ та $10^{-6}(6) \mathrm{mg} / \mathrm{ml}(B)$

Рис. 3. Криві суперпреципітації актоміозину серцевого м'яза в контролі (1) та за наявності клітиннозв'язаного білка А золотистого стафілокока в концентраціях $10^{-2}$ (2); $10^{-3}$ (3); $10^{-4}$ (4) і 10-5 (5) мг/мл $(\boldsymbol{A})$ та за наявності очищеного білка А золотистого стафрілокока в концентраціях $10^{-2}(2) ; 10^{-3}(3)$; $10^{-4}(4) ; 10^{-5}(5)$ і $10^{-6}(6)$ мг/мл (B)

Calculation of SPP normalized maximum rate showed that $\mathrm{pA}$ in both purified and in cell wall associated form is a powerful activator of actomyosin complex formation. Therefore, this substance causes more than doubled increase of $v_{n}$ parameter over the entire range of studied concentrations (Fig. 4, B).

The obtained results allow us to speculate that staphylococcus pA alters the kinetics of interaction between actin and myosin thus that his presence reduces the size of actin and myosin heads conglomerates, but increases the rate of their aggregation. Characteristics of the SPP kinetic curves $\left(D_{\max }, v_{0}\right.$ and $\left.t_{1 / 2}\right)$ in the presence of various concentrations of purified and cell-bound PA are presented in Tabl. 2 and Fig. $4, B$.

The data about changes of the SPP reaction kinetics confirms the predictions on the possible contact between pA molecules and proteins of contractile apparatus that is based on data obtained from the investigations of ATPase activity of contractile proteins $[6,10]$. At the same time, kinetic curves of actomyosin SPP confirm theory about significant biological activity of $\mathrm{CBpA}$. Thus, we can assume that $\mathrm{pA}$ is able to interact directly with the contractile proteins exceptionally in case of penetration inside cardiomyocytes $[4,6,10,13]$.

ISSN 1996-4536 (print) • ISSN 2311-0783 (on-line) • Біологічні Студії / Studia Biologica • 2014 • Том 8/№3-4 • С. 53-60 
Thus, our studies have shown that $\mathrm{Sr}^{2+}, \mathrm{Zn}^{2+}, \mathrm{Cd}^{2+}$ may provide actomyosin SPP the reaction, but in various degrees in relation to control - depending on the presence of certain ions, which can cause activation or inhibition of this process, respectively. It's revealed that protein $A$ effects on kinetics of myocardium actomyosin SPP reaction, and cell-bound form of $\mathrm{pA}$ is characterized by higher activity.

Table 2. Effect of Staphylococcus aureus protein A on the parameters of myocardium actomyosin SPP curves $(n=5)$

Таблиця 2. Вплив білка А золотистого стафрілокока на параметри кривих суперпреципітації актоміозину серцевого м'яза $(\mathrm{n}=5)$

\begin{tabular}{c|c|c|c|c}
\hline Protein A concentration, & \multicolumn{2}{|c|}{ Cell-bound protein A } & \multicolumn{2}{c}{ Purified protein A } \\
\cline { 2 - 5 } $\mathrm{mg} / \mathrm{ml}$ & $D_{\max }$ & $t_{1 / 2}, \min$ & $D_{\max }$ & $t_{1 / 2}, \min$ \\
\hline 0 (control) & $0.61 \pm 0.02$ & $3.2 \pm 0.14$ & $1.25 \pm 0.03$ & $1.6 \pm 0.02$ \\
$10^{-6}$ & - & - & $0.9 \pm 0.01^{*}$ & $0.5 \pm 0.01^{*}$ \\
$10^{-5}$ & $0.49 \pm 0.02^{*}$ & $2.5 \pm 0.09^{*}$ & $1.2 \pm 0.02$ & $1.1 \pm 0.02^{*}$ \\
$10^{-4}$ & $0.5 \pm 0.02^{*}$ & $2.8 \pm 0.11$ & $1.0 \pm 0.02^{*}$ & $0.7 \pm 0.01^{*}$ \\
$10^{-3}$ & $0.56 \pm 0.02$ & $2.7 \pm 0.08^{*}$ & $1.35 \pm 0.04$ & $1.8 \pm 0.03$ \\
$10^{-2}$ & $0.56 \pm 0.01$ & $2.6 \pm 0.06^{*}$ & $1.25 \pm 0.02$ & $0.75 \pm 0.01^{*}$ \\
\hline
\end{tabular}

Comment: * $-\mathrm{P}<0.05$ (vs control).

Примітка: * $-\mathrm{P}<0,05$ (щодо контролю).

$A$

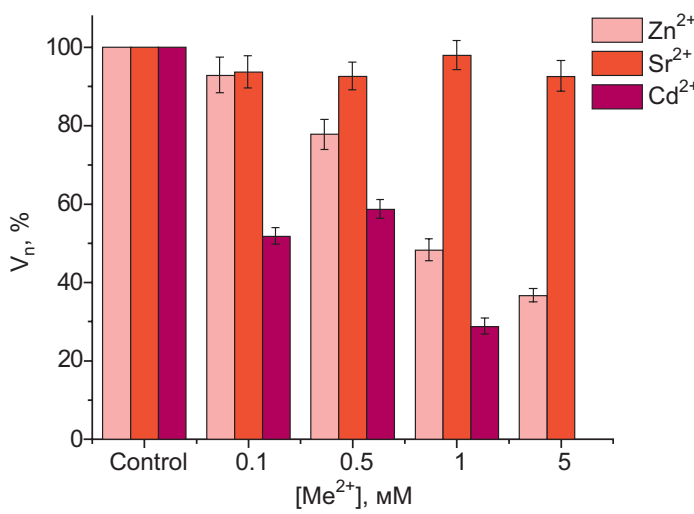

$B$

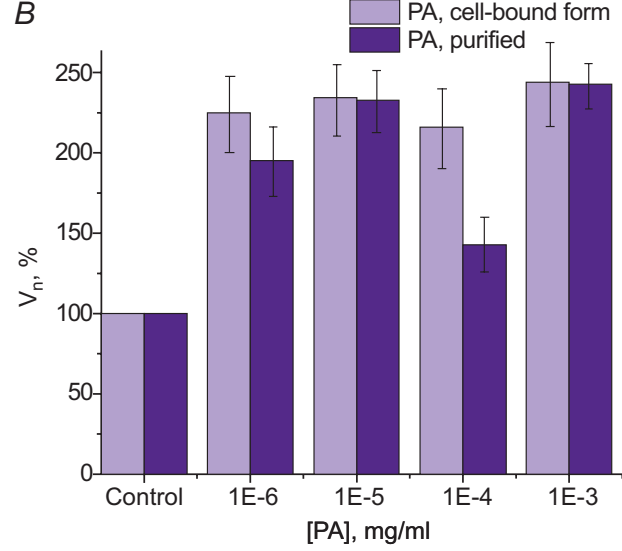

Fig. 4. Modulation of normalized maximum of myocardium actomyosin SPP rates: $\boldsymbol{A}$ - in the presence of heavy metal ions; $\boldsymbol{B}$ - in the presence of protein A Staphylococcus aureus (purified and cell-bound form). The reference values are $100 \%(n=5)$

Рис. 4. Модуляція показників нормованої максимальної швидкості реакції суперпреципітації актоміозину серцевого м'яза: $\boldsymbol{A}$ - за наявності іонів важких металів; $\boldsymbol{B}$ - за наявності очищеного та клітиннозв'язаного білка А золотистого стафрілокока. Щодо контролю, прийнятого за 100 \% ( $n=5)$

The obtained results intensify our current conceptions about importance of physical and chemical environmental factors and staphylococcus active substances on the function of the myocardium contractile proteins and are important for the further development of effective methods of human organism protection from the toxic activity of metal ions. However, the accumulated data not only complement our knowledge of the mechanism of action of metal ions on living organisms, but also give a possibility to predict regularities and active mechanism of other cations (based on analysis of their physical 
and chemical properties). In other words, obtained results can be used in future biophysical as well as physiological or environmental studies.

\section{ACKNOWLEDGEMENTS}

Authors would like to by gratitude sincere to Prof. L.S. Kholodna for kindly presenting of protein $\mathrm{A}$.

1. Andreichenko K., Prylutska S., Medynska K. et al. Impact of carbon nanotubes on ATPase activity and superprecipitation reaction of natural actomyosin. Int. J. Physiol. Pathophysiol, 2012; 3(4): 341-347.

2. Andreichenko K.S., Prylutska S.V., Medynska K.O. et al. Effect of fullerene $\mathrm{C}_{60}$ on ATPase activity and superprecipitation of skeletal muscle actomyosin. Ukr. Biokhim. Zh, 2013; 85(2): 20-26.

3. Bogutska K.I., Prylutskyy Yu.I. Influence of zinc ions on the myosin ATPase activity and superprecipitation reaction of actomyosin of cardiac muscle. Biopolym. Cell, 2011; 27(6): 446-452.

4. Boyer L., Doye A., Rolando M. et al. Induction of transient macroapertures in endothelial cells through RhoA inhibition by Staphylococcus aureus factors. J. Cell. Biol, 2006; 173(5): 809-819.

5. Burdyga Th.V., Kosterin S.A. Kinetic analysis of smooth muscle relaxation. Gen. Physiol. Biophys, 1991; 10: 589-598.

6. Davidovskaya T.L., Tsimbalyuk O.V., Danilova V.M. et al. The effect of staphylococcus active substances on the ATPase activity of smooth muscle natural actomyosin and myosin. Ukr. Biokhim. Zh, 2001; 73(4): 24-28.

7. Davidovskaya T.L., Tsimbalyuk O.V., Miroshnichenko M.S. Staphylococcus toxin modulates the regulatory mechanisms of contraction-relaxation of ring smooth muscles of the thick intestine. Biopolym. Cell, 2001; 17(1): 36-42.

8. Kobayashi S.D., DeLeo F.R. Staphylococcus aureus protein A promotes immune suppression. Mbio, 2013; 4(5): e00764-e007613. doi: 10.1128/mBio.00764-13.

9. Koubassova N.A., Tsaturyan A.K. Molecular mechanism of actin-myosin motor in muscle. Biochemistry, 2011; 76: 1484-1506. (In Russian).

10. Melenevs'ka N.V., Miroshnychenko M.S., Shuba M.F. Modulation of molecular signaling mechanisms in excitable cells by toxins and bacterial substances. Ukr. Biokhim. Zh, 2005; 77(3): 27-34.

11. Mutig N., Geers-Knoerr C., Piep B. et al. Lipoteichoic acid from Staphylococcus aureus directly affects cardiomyocyte contractility and calcium transients. Mol. Immunol, 2013; 56(4): 720-728.

12. Rossier O.M., Gauthier N., Biais N. et al. Force generated by actomyosin contraction builds bridges between adhesive contacts. The EMBO J, 2010; 29: 1055-1068.

13. Saraya T., Chinen K., Hirano K., Goto H. Massive myocardial abscesses caused by methicillin-susceptible Staphylococcus aureus. Intern. Med, 2013; 52(17): 1999.

14. Svíglerová J., Kuncová J., Stengl M. Contractile functions of myocardium and their regulation. Cesk Fysiol, 2014; 63(1): 25-33.

15. Tartakovskiy A.D. Methods of isolation and characterization of myosin and its subunits from striated muscle. Biophysical and biochemical methods for studying muscle proteins. Leningrad: Nauka, 1978; 55-76. (in Russian).

16. Tikunov B.A. The effect of magnesium ions on the two-stage kinetics of superprecipitation and ATPase activity of natural actomyosin. Biokhimiia, 1990; 55(5): 822-828. (In Russian).

17. Tkachev Y.V., Ge J., Negrashov I.V., Nesmelov Y.E. Metal cation controls myosin and actomyosin kinetics. Protein Sci, 2013; 22(12): 1766-1774.

18. Tsymbalyuk O.V. Comparative analysis of the mechanokinetics of contractile activity of myometrium smooth muscles under calixarene C-99 and ouabain action. Studia Biologica, 2014; 8(1): 63-72.

ISSN 1996-4536 (print) • ISSN 2311-0783 (on-line) • Біологічні Студії / Studia Biologica • 2014 • Том 8/№3-4 • С. 53-60 


\title{
ОСОБЛИВОСТІ РЕАКЦІЇ СУПЕРПРЕЦИПІТАЦІЇ АКТОМІОЗИНУ В РІЗНИХ УМОВАХ ОТОЧУЮЧОГО СЕРЕДОВИЩА
}

\author{
О. В. Цимбалюк, К. І. Богуцька, О. Ю. Нипорко, Т. Л. Давидовська \\ Київський національний університет імені Тараса Шевченка \\ вул. Володимирська, 64/13, Київ 01601, Україна \\ e-mail: otsymbal@bigmir.net
}

Вплив іонів металів $\left(\mathrm{Cd}^{2+}, \mathrm{Zn}^{2+}, \mathrm{Sr}^{2+}\right)$ та білка А стафрілокока на реакцію суперпреципітації актоміозину серцевого м'яза було досліджено за допомогою методів препаративної білкової хімії, оптичної спектроскопії та кінетичного аналізу. З'ясовано, що за концентрації 0,1-5 мМ іони металів пригнічують $\mathrm{Mg}^{2+}$-залежну реакцію суперпреципітації актоміозину серцевого м'яза і змінюють кінетичні хакрактеристики цього процесу. Встановлено, що білок А модулює динаміку суперпреципітації, зменшуючи максимальне значення оптичної щільності та час досягнення її напівмаксимуму, а також збільшує початкову і нормовану максимальну швидкості суперпреципітації. Отже, досліджені фрактори можуть впливати на актин-міозинову взаємодію, змінюючи функціональні характеристики білків скорочувального комплексу кардіоміоцитів. Кінетичні характеристики суперпреципітації актоміозину є чутливими до дії фрізикохімічних і фрармакологічних фракторів та можуть бути використані для дослідження їх впливу на молекулярні механізми м'язового скорочення.

Ключові слова: актоміозин, суперпреципітація, кінетичні параметри, іони металів, білок А стафілокока, серцевий м'яз.

\section{ОСОБЕННОСТИ РЕАКЦИИ СУПЕРПРЕЦИПИТАЦИИ АКТОМИОЗИНА В РАЗНЫХ УСЛОВИЯХ ОКРУЖАЮЩЕЙ СРЕДЫ}

\author{
О. В. Цимбалюк, Е. И. Богуцкая, А. Ю. Ныпорко, Т. Л. Давидовская \\ Киевский национальный университет имени Тараса Шевченко \\ ул. Владимирская, 64/13, Киев 01601, Украина \\ e-mail: otsymbal@bigmir.net
}

Влияние ионов металлов $\left(\mathrm{Cd}^{2+}, \mathrm{Zn}^{2+}, \mathrm{Sr}^{2+}\right)$ и белка А стафилококка на реакцию суперпреципитации актомиозина сердечной мышцы было исследовано с помощью методов препаративной белковой химии, оптической спектроскопии и кинетического анализа. Показано, что при концентрации 0,1-5 мМ ионы металлов подавляют $\mathrm{Mg}^{2+}$ зависимую реакцию суперпреципитации актомиозина сердечной мышцы и изменяют кинетические характеристики этого процесса. Установлено, что белок А модулирует динамику суперпреципитации, уменьшая максимальное значение оптической плотности и достижение ее полумаксимума, а также увеличивает начальную и нормированную максимальную скорости суперпреципитации. Таким образом, исследованные фракторы способны влиять на актин-миозиновое взаимодействие, меняя фрункциональные характеристики белков сократительного комплекса кардиомиоцитов. Кинетические характеристики суперпреципитации актомиозина чувствительны к действию физико-химических и фармакологических фракторов и могут быть использованы для изучения их влияния на молекулярные механизмы мышечного сокращения.

Ключевые слова: актомиозин, суперпреципитация, кинетические параметры, ионы металлов, белок А стафилококка, сердечная мышца.

Одержано: 13.10 .2014

ISSN 1996-4536 (print) • ISSN 2311-0783 (on-line) • Біологічні Студії / Studia Biologica • 2014 • Том 8/№3-4 • C. 53-60 